\title{
A Role for Lymphocytes and Cytokines on the Eosinophil Migration Induced by LPS
}

\author{
Hugo C Castro-Faria-Neto ${ }^{+}$, Carmen M Penido, Andréa P Larangeira, \\ Adriana R Silva, Patrícia T Bozza
}

Núcleo de Imunofarmacologia, Departamento de Fisiologia e Farmacodinâmica, Instituto Oswaldo Cruz, Av. Brasil 4365, 21045-900 Rio de Janeiro, RJ, Brasil.

In the present work we review the existing evidence for a LPS-induced cytokine-mediated eosinophil accumulation in a model of acute inflammation. Intrathoracic administration of LPS into rodents (mice, rats or guinea pigs) induces a significant increase in the number of eosinophils recovered from the pleural fluid $24 \mathrm{hr}$ later. This phenomenon is preceded by a neutrophil influx and accompanied by lymphocyte and monocyte accumulation. The eosinophil accumulation induced by LPS is not affected by inhibitors of cyclo or lipoxygenase nor by PAF antagonists but can be blocked by dexamethasone or the protein synthesis inhibitor cycloheximide. Transfer of cell-free pleural wash from LPS injected rats (LPS-PW) to naive recipient animals induces a selective eosinophil accumulation within $24 \mathrm{hr}$. The eosinophilotactic activity present on the LPS-PW has a molecular weight ranging between 10 and 50 $k D a$ and its effect is abolished by trypsin digestion of the pleural wash indicating the proteic nature of this activity. The production of the eosinophilotactic activity depends on the interaction between macrophages and T-lymphocytes and its effect can not be blocked by anti-IL-5 monoclonal antibodies. Accumulated evidence suggest that the eosinophil accumulation induced by LPS is a consequence of a eosinophilotactic cytokine produced through macrophage and T-cell interactions in the site of a LPSinduced inflammatory reaction.

Key words: LPS - eosinophil - macrophages - T-cells - cytokine

\section{PLEURAL INFLAMMATION INDUCED BY LPS}

LPS is classically known as capable of inducing an inflammatory reaction when injected locally in the tissues. This phenomenon is characterized by an early neutrophil influx followed by a late mononuclear cell accumulation (Issekutz et al. 1987). We have previously demonstrated that the injection of LPS in the pleural cavity of rats, mice or guinea pigs induces an acute $(4 \mathrm{hr})$ neutrophil accumulation that can be inhibited by pretreatment with PAF antagonists. Simultaneously, a decrease in the number of neutrophils in the bone marrow and an increase in blood neutrophils was observed, indicating that neutrophils were being mobilized from the bone marrow pool of cells by LPS stimulation (Bozza et al. 1993b). In addition, eosinophils and mononuclear cells also accumulated in the pleural cavity of LPS injected animals after 24 $\mathrm{hr}$. The number of those cells remained above control values for at least $96 \mathrm{hr}$ (Bozza et al. 1991).

This work was supported by PAPES, CAPES, CNPq and FAPERJ.

Corresponding author. Fax:: +55-21-590.9490

Received 3 September 1997

Accepted 30 September 1997
Despite many attempts using different doses of LPS we could not detect increased vascular permeability, i.e. plasma leakage, in any of the time points analyzed.

It is interesting to point out that until that work, the ability of LPS in inducing eosinophil accumulation had not been studied thoroughly. Actually, only Folkerts et al. (1988) had detected an increase in eosinophil numbers in the brochoalveolar lavage of LPS stimulated guinea pigs. This fact led us to further investigate the mechanism by which LPS induces eosinophil accumulation.

\section{PHARMACOLOGICAL MODULATION OF LPS-IN- DUCED EOSINOPHIL ACCUMULATION}

The eosinophil accumulation induced by LPS is not a consequence of a direct chemotactic effect of LPS upon eosinophils since LPS is not able to induce eosinophil migration in vitro (Bozza et al. 1991). This led us to investigate the involvement of endogenous mediators that could account for the eosinophil accumulation observed after LPS challenge. Several mediators can trigger eosinophil accumulation in the course of an acute inflammatory response. Among those, $\mathrm{PAF}, \mathrm{LTB}_{4}$ (Silva et al. 1991) and bradykinin (Pasquale et al. 1991) were shown to induce delayed and long-lasting eosinophil infiltration in the rat pleural cavity. 
Nevertheless, none of these mediators seem to be involved on LPS-induced eosinophil accumulation (Bozza et al. 1993a). Pretreatment with a cyclooxygenase inhibitor (indomethacin), a dual cyclo/lipoxygenase (BW755C), a more specific lipoxygenase inhibitor (BWA4C), PAF receptor antagonists (PCA 4248 and WEB 2086), a combination of BWA4C and WEB 2086, or a bradyki$\operatorname{nin} \mathrm{B}_{2}$ receptor antagonist (HOE 140) failed to diminish the eosinophil influx induced by LPS (Bozza et al. 1993a; unpublished results). By contrast, dexamethasone and the protein synthesis inhibitor, cycloheximide, were able to abolish LPSinduced eosinophil accumulation (Bozza et al. 1993a).

Dexamethasone has different effects that could explain its inhibition of LPS-induced eosinophil accumulation. For instance, dexamethasone is able to induce the synthesis of lipocortins with consequent inhibition of phospholipase $\mathrm{A}_{2}$ and thus inhibition of eicosanoids and PAF synthesis. Nevertheless, in view of the above mentioned results using selective blockers of eicosanoid synthesis and PAF receptor, it is unlikely that this action of dexamethasone is accounting for the inhibition of eosinophil accumulation. Dexamethasone can also directly inhibit the transcription of some genes coding for cytokines such as GM-CSF and IL-3, both able to induce eosinophil activation (Owen et al. 1987, Rothenberg et al. 1989). Together with the results obtained with the protein synthesis inhibitor cycloheximide, which also inhibited LPS-induced eosinophil accumulation, we can further suggest that the increase in the number of pleural eosinophils following LPS stimulation requires the synthesis of a proteic factor, probably a cytokine.

\section{DETECTION OF EOSINOPHILOTACTIC ACTIVITY IN} THE PLEURAL WASH OF LPS-INJECTED ANIMALS

Based on the results obtained with the pharmacological experiments, we aimed to clarify whether a protein with eosinophilotactic activity has been produced and released in the inflammatory fluid of LPS-injected animals. Firstly, we demonstrated that the cell-free pleural wash of LPS-injected animals (LPS-PW) is able to induce eosinophil accumulation when injected intrathoracically in recipient naive animals or in animals pretreated with dexamethasone or cycloheximide (Bozza et al. 1993a). These results indicate that a factor with eosinophil chemoattractant activity is released in the pleural cavity after LPS stimulation.

Furthermore, these results also indicate that the eosinophilotactic activity in the pleural wash is not the result of LPS contamination since dexamethasone and cycloheximide inhibit eosinophil accumulation induced by LPS itself but do not affect the one induced by the injection of LPS-PW.

In contrast to other known eosinophil acting cytokines such as IL-3 (Ulich et al. 1989), TNF (Ulich et al. 1991), IL-8 (Collins et al. 1993) and IL-5 (Warren \& Moore 1988), the eosinophilotactic activity in the LPS-PW could not be destroyed by $30 \mathrm{~min}$ boiling indicating that this activity is heatstable. Nevertheless, completely loss of activity was obtained when LPS-PW was incubated with trypsin for $30 \mathrm{~min}$ at $37^{\circ} \mathrm{C}$, adding support to the interpretation that the activity resides on a newly synthesized protein. Ultrafiltration of LPS-PW showed that this protein has a molecular weight in the range of 10 to $50 \mathrm{kDa}$ (Bozza et al. 1993a).

It is important to note that, although IL-5 is able to induce eosinophil accumulation in the pleural cavity and seems to account for the eosinophilia observed in allergic inflammatory reactions (Kaneko et al. 1991, Bozza et al. 1994), incubation of LPS-PW with anti-IL-5 monoclonal antibodies did not inhibited the eosinophil attractant activity present in the pleural wash showing that an eosinophilotactic factor different from IL-5 is responsible for the activity in the LPS-PW. Furthermore, semi-purified LPS-PW was unable to displace the binding of ${ }^{125}$ I - RANTES to isolated guinea pigs eosinophils (Bozza et al. unpublished observations) indicating that the activity in LPSPW is different from the eosinophilotactic chemokine RANTES as well. Other eosinophil attractant chemokines such as MCP-2 (Chang et al. 1989), MCP-3 (Van Damme et al. 1992), and eotaxin (Jose et al. 1994) have been identified but their involvement on LPS-induced eosinophil accumulation remains to be determined.

\section{CELLULAR SOURCE OF THE EOSINOPHILOTACTIC ACTIVITY PRESENT IN THE LPS-PW}

Cells accumulating in the site of an inflammatory reaction can contribute to its development by secreting inflammatory mediators such as bioactive lipids, peptides, amines and proteins. Therefore, we hypothesized that one of the resident cells or cells infiltrating the pleural cavity during the initial stages of LPS-induced inflammation could be involved in the production of the factor responsible for the late eosinophil accumulation observed. In this respect, we have shown (Bozza et al. 1994) that the depletion of neutrophils or platelets by the use of specific antibodies did not affect the eosinophil influx induced by LPS. Also, the induction of mast cell degranulation by pre-exposure to low doses of polymixin B could not interfere with the phenomenon. It is important to note, that all those three cell populations are potential sources of eosinophil chemotactic factors since they are able to produce and/or secrete IL-8, RANTES and 
ECF-A, respectively (Schwartz 1987, Striter et al. 1990, Kameyoshi et al. 1992).

T-lymphocytes are also another major source of eosinophil chemoattractant cytokines. Those cells are generally believed to mediate the eosinophil accumulation observed during allergic reactions and parasitic infections through a mechanism dependent on IL-5 (Spry 1988, Frew et al. 1989, Iwamoto et al. 1992). To investigate the putative involvement of lymphocytes on the eosinophil accumulation triggered by LPS the animals were pretreated with cyclosporin A, an inhibitor of T-lymphocyte activation (Borel 1989). Under this condition, LPS-induced eosinophil accumulation was drastically reduced suggesting that lymphocytes might play at least a partial role in the phenomenon. This result was confirmed by the depletion of T-lymphocytes using an anti-Thy 1.0 monoclonal antibody which also decreased LPS-induced eosinophil accumulation (Bozza et al. 1994). We have observed that T-lymphocytes of the $\gamma \delta^{+}$-subtype infiltrate in the pleural cavity after LPS stimulation whereas $\mathrm{CD}^{+} \mathrm{T}$-cell and $\mathrm{CD} 8^{+} \mathrm{T}$-cell subsets did not. Depletion of $\gamma \delta^{+} \mathrm{T}$-cell subset with a monoclonal antibody, but not the depletion of $\mathrm{CD}^{+}$ $\mathrm{T}$-cell or $\mathrm{CD} 8^{+} \mathrm{T}$-cell subsets, markedly reduced the eosinophil accumulation suggesting that $\gamma \delta^{+}$ $\mathrm{T}$-cell is the subset of T-lymphocytes involved on the eosinophilotactic response to LPS (Penido et al. 1997).

Macrophages and monocytes express high amounts of the LPS receptor, CD14, and are able to produce and release a variety of cytokines and chemokines upon LPS stimulation (Rietchel \& Blade 1992, Ziegler-Heitbrock \& Ulevitch 1993, Meheus et al. 1993). These features make resident macrophages good candidates as source of the eosinophilotactic activity detected in the LPS-PW. To investigate this possibility resident pleural macrophages were depleted by means of an intrapleural injection of liposomes containing dichloromethylene diphosphonate. We have previously demonstrated that this procedure was able to induce a selective depletion of pleural macrophages within five days (Bozza et al. 1994) and has no effect on other cells at the same time. In fact, when the animals were pretreated with liposomeentrapped dichloromethylene diphosphonate an inhibition of LPS-induced eosinophil accumulation was observed. This inhibition was not observed when LPS-PW, instead of LPS, was injected into macrophage-depleted animals, indicating that resident macrophages are involved in the production of the eosinophilotactic activity found on LPS-PW rather then contributing to its effect. Moreover, the injection of the supernatant recovered from monolayers of cultured pleural macrophages stimulated by LPS was able to induce eosinophil accumulation in naive animals (Bozza et al. 1994) which reinforce the hypothesis mentioned above.

In summary, the eosinophil accumulation induced by LPS appears to involve the synthesis of a protein with molecular weight between 10 and $50 \mathrm{kDa}$. The presence of T-lymphocytes and macrophages seems to be required to the full development of the eosinophil response to LPS (Fig.). Whether this protein is one of the known eosinophilotactic factors already described or a new cytokine with eosinophil chemoattractant activity will await the isolation and sequence determination of this eosinophilotactic protein.

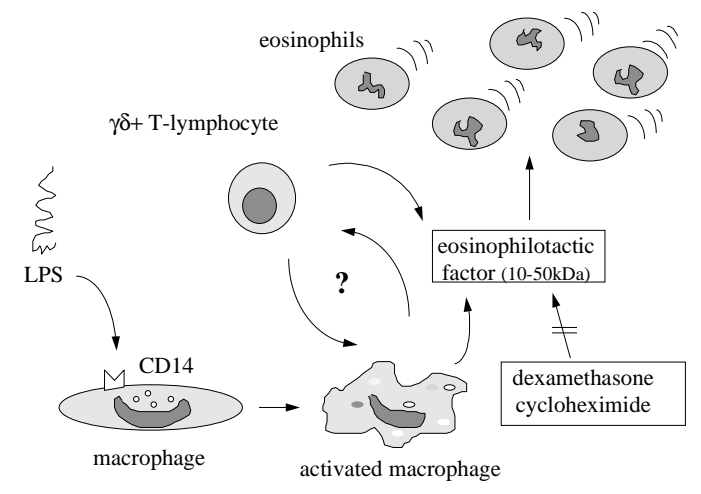

Schematic summary of the present knowledge about the mechanism of LPS-induced eosinophil accumulation.

\section{ACKNOWLEDGMENTS}

To Dr MGMO Henriques, Dr MA Martins, Dr PMR Silva, Dr RR Santos and Dr RSB Cordeiro whose contributions were important in different parts of this work. PTB is a PEW fellow in biomedical research.

\section{REFERENCES}

Borel JF 1989. Pharmacology of cyclosporine (Sandimmune) IV. pharmacological properties in vivo. Pharmacol Rev 41: 259-351.

Bozza PT, Castro-Faria-Neto HC, Pires ALA, Silva PMR, Martins MA, Cordeiro RSB 1991. Endotoxin induces eosinophil accumulation in the rat pleural cavity. Brazilian J Med Biol Res 24: 957-960.

Bozza PT, Castro-Faria-Neto HC, Martins MA, Larangeira AP, Perales JE, Silva PMR, Cordeiro, RSB 1993a. Pharmacological modulation of lipopolisaccharide-induced pleural eosinophilia in the rat: a role for a newly generated protein. Eur $J$ Pharmacol 248: 41-47.

Bozza PT, Castro-Faria-Neto HC, Silva AR, Larangeira AP, Silva PMR, Martins MA, Cordeiro RSB 1993b. Lipopolisaccharide-induced pleural neutrophil accumulation depends on marrow neutrophils and platelet-activating factor. Eur J Pharmacol 270: 143-149.

Bozza PT, Castro-Faria-Neto HC, Penido C, Larangeira AP, Henriques MGMO, Silva PMR, Martins MA, 
Santos RR, Cordeiro RSB 1994. Requirement for lymphocytes and resident macrophages in LPS-induced pleural eosinophil accumulation. J Leukoc Biol 56: 151-158.

Chang HC, Hsu F, Freeman GJ, Griffin JD, Freeman GJ, Griffin JD, Reinherz 1989. Cloning and expression of a gamma-interferon-inducible gene in monocytes: a new member of the cytokine gene family. Int Immunol 1: 388-396.

Collins PD, Weg VB, Faccioli LH, Watson ML, Moqbel R, Williams TJ 1993. Eosinophil accumulation induced by human interleukin-8 in guinea-pig in vivo. Immunology 79: 312-318.

Folkerts G, Henricks PAJ, Slootweg PJ, Nijkamp FP 1988. Endotoxin-induced inflammation and injury of the guinea-pig respiratory airways cause bronchial hyporreactivity. Am Rev Respir Dis 137: 14411448.

Frew AJ, Corrigan CJ, Maestrelli P, Tsai J-J, Kurihara K, O'Heir RE, Hartnell A, Cromwell O, Kay AB 1989. T lymphocytes in allergen-induced late-phase reactions and asthma. Int Arch Allergy Appl Immunol 88: 63.

Issekutz AC, Megyeri P, Issekutz TB 1987. Role of macrophage products in endotoxin-induced polymorphonuclear leukocyte accumulation during inflammation. Lab Invest 56: 49-59.

Iwamoto I, Tomoe S, Tomioka H, Takatsu K, Yoshida S 1992. Role of CD4 ${ }^{+}$T lymphocytes and interleukin5 in antigen-induced eosinophil recruitment into the site of cutaneous late-phase reaction in mice. J Leuk Biol 52: 572-578.

Jose PJ, Griffiths-Johnson DA, Collins PD, Walsh DT, Moqbel R, Totty NF, Truong O., Hsuan JJ, Williams TJ 1994. Eotaxin: A potent eosinophil chemoattractant cytokine detected in a guinea-pig model of allergic airways inflammation. J Exp Med 179: 881-887.

Kameyoshi Y, Doorschner A, Mallet AI, Christophers E, Schroder JM 1992. Cytokine RANTES released by thrombin-stimulated platelets is a potent attractant for human eosinophils. J Exp Med 176: 587.

Kaneko M, Hitoshi Y, Matsumoto S 1991. Role of interleukin-5 in local accumulation of eosinophils in mouse allergic peritonites. Int Arch Allergy Appl Immunol 96: 41-45.

Meheus LA, Fransen LM, Raymackers JG, Blockx HA, Van Beeumen JJ, Van Bun SM, Van de Voorde A 1993. Identification by microsequencing of lipopolysaccharide-induced proteins secreted by mouse macrophages. J Immunol 151: 1535-1547.

Owen WF, Rothenberg ME, Silberstein DS, Gasson JC, Stevens RL, Austen KF 1987. Regulation of human eosinophil viability, density, and function by granulocyte-macrophage colony-stimulating factor in the presence of 3T3 fibroblasts. J Exp Med 166: 129-
141.

Pasquale CP, Martins MA, Bozza PT, Silva PMR, CastroFaria-Neto HC, Pires AL, Cordeiro RSB 1991. Bradykinin induces eosinophil accumulation in the rat pleural cavity. Int Arch Allergy Appl Immunol 95: 244-247.

Penido CM, Castro-Faria-Neto HC, Larangeira AP, Santos RR, Bozza PT, Henriques MGMO 1997. A role for $\gamma \delta^{+}$T-lymphocytes on the eosinophil migration induced by LPS in mice. J Immunol 159: 853-860.

Rietschel ET, Brade H 1992. Bacterial endotoxins. Sci Amer 267: 26-33.

Rothenberg ME, Petersen J, Stevens RL, Silberstein DS, McKenzie DT, Austen KF, Owen WFJr 1989. IL-5dependent conversion of normodense human eosinophils to the hypodense phenotype uses 3T3 fibroblasts for enhanced viability, accelerated hypodensity, and sustained antibody-dependent cytotoxicity. J Immunol 143: 2311-2316.

Schwartz LB 1987. Mediators of human mast cell and human mast cell subsets. Ann Allergy 58: 226-235.

Silva PMR, Martins MA, Castro-Faria-Neto HC, Cordeiro RSB, Vargaftig BB 1991. Generation of an eosinophilotactic activity in the pleural cavity of platelet-activating factor-injected rats. J Pharmacol Exp Ther 257: 1039-1044.

Spry CJF 1988. Eosinophils: a comprehensive review and guide to the scientific and medical literature. Oxford University, Oxford, UK. 127 pp.

Striter RM, Kasahara K, Allen R, Showell HJ, Standiford TJ, Kunkel SL 1990. Human neutrophils exhibit disparate chemotactic factor gene expression. Biochem Biophis Res Commun 173: 725.

Ulich TR, Castillo J, Busser K, Guo K, Yin S 1989. Acute in vivo effects of IL-3 alone and in combination with IL- 6 on the blood cells of the circulation and bone marrow. Am J Pathol 135: 663-670.

Ulich TR, Watson LR, Yin S, Guo K, Wang P, Thang H, Castillo J 1991. The intratracheal administration of endotoxin and cytokines: Characterization of LPSinduced IL-1 and TNF mRNA expression and the LPS-, IL-1-, and TNF-induced inflammatory infiltrate. Am J Pathol 138: 1485-1496.

Van Damme J, Proost P, Lenaerts J-P, Opdenakker G 1992. Structural and functional identification of two human, tumor-derived monocyte chemotactic proteins (MCP-2 and MCP-3) belonging to the chemokine family. J Exp Med 176: 59-69.

Warren DJ, Moore MAS 1988. Synergism among interleukin-1, interleukin-3 and interleukin-5 in the production of eosinophils from primitive hemopoietic stem cells. J Immunol 140: 94-98.

Ziegler-Heitbrock HWL, Ulevitch RJ, 1993. CD14: cell surface receptor and differentiation marker. Immunol Today 14: 121-125. 